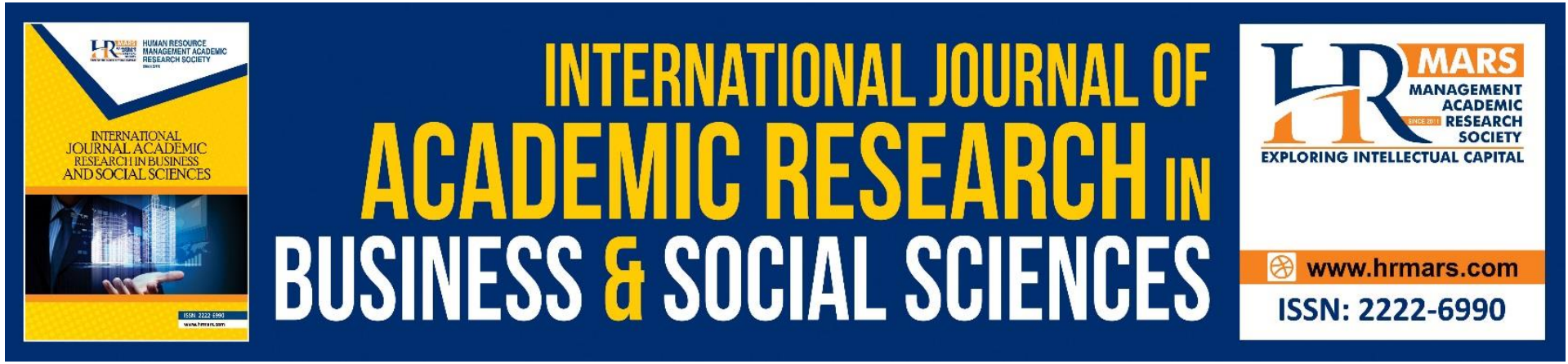

\title{
Hang Tuah: A Malay Icon Transcending Time
}

\author{
Rozita Che Rodi, Hashim Musa
}

To Link this Article: http://dx.doi.org/10.6007/IJARBSS/v11-i7/10066

DOI:10.6007/IJARBSS/v11-i7/10066

Received: 22 May 2021, Revised: 25 June 2021, Accepted: 17 July 2021

Published Online: 29 July 2021

In-Text Citation: (Rodi \& Musa, 2021)

To Cite this Article: Rodi, R. C., \& Musa, H. (2021). Hang Tuah: A Malay Icon Transcending Time. International Journal of Academic Research in Business and Social Sciences, 11(7), 1360-1382.

Copyright: (c) 2021 The Author(s)

Published by Human Resource Management Academic Research Society (www.hrmars.com)

This article is published under the Creative Commons Attribution (CC BY 4.0) license. Anyone may reproduce, distribute, translate and create derivative works of this article (for both commercial and non-commercial purposes), subject to full attribution to the original publication and authors. The full terms of this license may be seen

at: http://creativecommons.org/licences/by/4.0/legalcode

Vol. 11, No. 7, 2021, Pg. 1360 - 1382

http://hrmars.com/index.php/pages/detail/IJARBSS

JOURNAL HOMEPAGE

Full Terms \& Conditions of access and use can be found at

http://hrmars.com/index.php/pages/detail/publication-ethics 


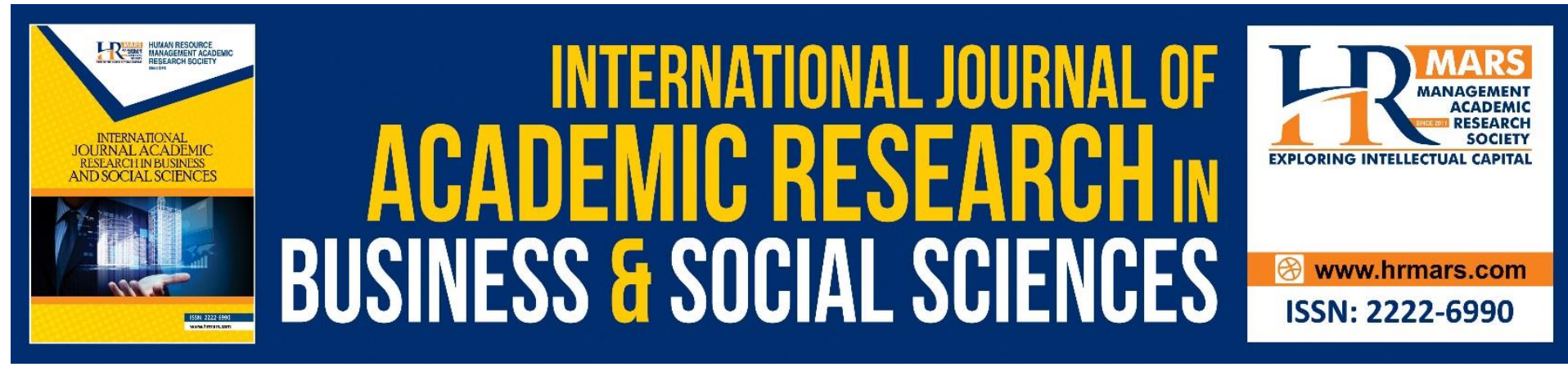

\title{
Hang Tuah: A Malay Icon Transcending Time
}

\author{
Rozita Che Rodi \\ Universiti Putra Malaysia Malaysia \\ Hashim Musa \\ Universiti Malaya Malaysia
}

\begin{abstract}
This article will focus discussion on the proof of the existence of Hang Tuah as a historical figure and an icon that symbolizes the Malay community's sense of heroism, velour, loyalty, uprightness, deep love for his country and king, and as a knowledgeable and universal man of the world, familiar with the customs and the ways of many foreign countries, conversant in ten world languages, a fearless warrior and a diplomat of a global standing. Hitherto many considered him to be a mere mythical figure. This article, however, will prove, using the primary and secondary data and artifacts as basis of study, that he was a living person, who had served with the greatest velour and loyalty in the court of the $15^{\text {th }}$ century kingdom of Malacca. The primary data comprising firstly the official court chronicle, the Rekidai Hŏan of the ancient Chinese Kingdom of Ryukyu, secondly the Commentaries of Great Afonso Dalboquerque: Second Viceroy of India, and thirdly the engraving on one of the walls of the remnants of ancient Indian Kingdom of Vijayanagara at Hampi, India, depicting the figure of Hang Tuah riding a horse. The secondary data comprising the Hikayat Hang Tuah and the Malay Annals (Sulalatus Salatin), both are well-known Malay literary historical works describing fully the exploits of Hang Tuah as the super hero of the Malay world. The findings in both the primary and secondary data proved beyond any doubt the existence of Hang Tuah in history, serving as a warrior, admiral and diplomat in the $15^{\text {th }}$ century Kingdom of Malacca. Further research on the sea journeys of Hang Tuah crossing seven seas, will no doubt strengthen further the character of Hang Tuah as an iconic Malay hero transcending times and ages.
\end{abstract}

Keywords: Icon, Psyche, Cultural Hero, Artifacts, Rekidai Hŏan, Afonso Dalbouquerque, Ryukyu.

\section{Introduction}

The character of Hang Tuah and his four companions; Hang Jebat, Hang Kasturi, Hang Lekir and Hang Lekiu, were exemplary personalities deeply entrenched in the hearts and mind or psyche of the Malays for several hundred years. As stated by the late Syed Nasir Ismail, who was among the greatest Malay nationalist and a former Director General of the Dewan Bahasa dan Pustaka ${ }^{1}$.

${ }^{1}$ A government body under the Ministry of Education in charge of uplifting the Malay language to become the national language of Malaysia: 


\begin{abstract}
"Their story (Hang Tuah and his four companions) was frequently narrated in the past until today, in various forms of oral story telling, dramatic plays and performances, and even in the form of movies. The Malays are never weary of listening to the stories of their valour and courage. For hundreds of years their bravery became the source of inspiration for the Malays to aspire in achieving the same great height now and in the future." (Kassim, 1966: v).
\end{abstract}

The fact that the name of Hang Tuah has been immortalized in naming housing estates, mosques, buildings, streets, stadiums, schools, a ship and even a university in in many parts of the Malay-speaking world such as in Peninsular Malaysia, Java, Sumatera, Riau, Sulawesi and etc, was a clear proof that he is very much revered and respected.

\title{
Research Problems and Objectives
}

There are two research problems to be solved in this article, namely, whether the character of Hang Tuah existed in history or just a mere mythical figure, and if he existed what were his actual roles in the kingdom of Malacca during the time of the golden era of the Malacca Sultanate in the $15^{\text {th }}$ Century and early $16^{\text {th }}$ C.E?

Guided by these two research problems, the article will prove that based on research data, Hang Tuah did exist in history, and that he was born in 1431 and he was still alive and 80 years old at the time of the fall of Malacca to the Portuguese in 1511. He served as a warrior and admiral under four Malacca Sultans; (i) Sultan Muzaffar Shah (1446-1459), (ii) Sultan Mansur Shah (1459-1477), (iii) Sultan Alauddin Ri ayat Shah (1477-1488) and the earlier phase of the reign of (iv) Sultan Mahmud Shah (1488-1511). (Kassim, 1966: v).

It shall be proven that his roles as a warrior, admiral with a noble ethical personality, his bravery, courage, prowess and loyalty, his knowledge as a wise diplomat and a polyglot international trader and traveler, made him nothing less an icon to be modeled upon by later generations transcending time.

\section{Literature Review}

The original source that mentioned the name of Hang Tuah was the Hikayat Hang Tuah, the longest Malay traditional prose $(146,000$ words), acknowledged to be one of the greatest Malay traditional literary works by the Yayasan Karyawan, a Malaysian governmentsponsored agency tasked with researching and publishing great Malay traditional literary works or karya agung Melayu. In 2001 UNESCO$^{2}$ has accepted the Hikayat Hang Tuah into the Memory of the World Programme International Register.

Remarking on the Hikayat Hang Tuah, Henk (2004: 127) from Leiden University, has stated that:

"The text (Hikayat Hang Tuah) greatness now lies in the fact that it still deals with the meaning of life, and such it could easily be read as a very strong novel which is well able to compete with other novels in terms of depth and elegance."

\footnotetext{
${ }^{2}$ United Nations Educational, Scientific and Cultural Organization.
} 
His statement that the Hikayat Hang Tuah should be read by taking lessons from episodes narrated in the text, was very pertinent indeed and for that purpose this article is written to fulfill that very relevant purport.

Another important personality that has given very pertinent remarks on the Hikayat Hang Tuah, is one of the recipient of Sasterawan Negara or National Laureate Emeritus Professor Muhammad Hj. Salleh, who said that:

"He (Hang Tuah) is person with an exemplary refined character, absolute loyalty, sensitive to the need of others, unselfish, self-sacrificing, with an attitude of sharing and caring with others, such qualities that were rarely found in that era. His is a reflection of a towering personality during an era of great world civilization of the 14th and 15th century. Through him, the author has send a message regarding the aspiration and station of the Malays, that Hang Tuah had resided and exalted in a great world civilization, and that he was not only an honourable person, very wise and skillful, but also was able to master any situation confronting him, with full knowledge of the people and their culture wherever he was. (Muhammad, 2003: 4).

Muhammad Haji Salleh in The Epicof Hang Tuah (2011: xi) his English translation of the Hikayat Hang Tuah, published by the Institut Terjemahan dan Buku Negara (ITBN), further remarks that:

"The Hikayat Hang Tuah, the Epic of Hang Tuah is the great narrative of the Malay Archipelago and has always inspired strong passions in its readers and audiences. The protagonist, Hang Tuah, is the nonpareil of culture heroes. Over the centuries he has helped Malays, Malaysians, Indonesians, Singaporeans, Southern Thais and Bruneians to define their social and moral ideals and given them pride in their national identity... For many generations he has been the model for old and young alike. Young boys playing at sword or keris fighting called themselves Hang Tuah, Hang Jebat, Hang Kasturi, Hang Lekir, and Hang Lekiu. While the older men and women would debate his role in Malaccan history... In short, while Hang Tuah has been present in the minds of the Malays for at least the last six centuries, he is still very much alive there today, as their symbol of self-sacrifice, achievement, patriotism and, not least, as the foremost symbol of their survival."

According to Kassim (1966: xiv) the Hikayat Hang Tuah is the only Malay traditional literary work that was authentically of a Malay origin with little foreign elements, unlike other works for example the Hikayat Cekel Wenang Pati with heavy Javanese influence, the Hikayat Seri Rama and Hikayat Sang Boma with Hindu epic influence, and the Hikayat Amir Hamzah and the Hikayat Muhammad Hanafiah from the Islamic sources.

Little is known about the author of the original work of the Hikayat Hang Tuah, as there was no mention of his name, unlike the Sulalatul Salatin also known as the Sejarah Melayu (The Malay Annal) the writer mentioned his name as Tun Muhammad also known as Tun Sri Lanang who was tasked with the job of compiling it in 1021 Hijriah (1612 C.E.). According scholars such as Braginsky (1990: 403) the year the Hikayat Hang Tuah was written between 
1688-1710 in Johore after Malacca was captured by the Dutch in 1641 and the Johore Malay kingdom entered into an alliance with the Dutch bringing relative peace in the region. According to the Indonesian scholar Sutrisno (1983: 56-60) there are currently more than 20 copies of the manuscripts of the Hikayat Hang Tuah found in various libraries and collection in Kuala Lumpur, Leiden, London, Cambridge, Manchester, Jakarta, Terengganu, and Singapore. According to the late Acehnese scholar Iskandar (1995: 302) probably the original version was in an oral form, with much of its parts either copied or originated from the Sulalatu Salatin, Hikayat Inderapura, Hikayat Meukuta Alam and the Bustanu Salatin, with 18 of the 28 episodes in the Hikayat Hang Tuah having close similarities with those found in the afore-mentioned works.

Regarding the effort to publish the manuscript of Hikayat Hang Tuah into the Latin script, perhaps the most well-known is the one done by Kassim Ahmad Hikayat Hang Tuah (menurut naskhah Dewan Bahasa dan Pustaka), first published by Dewan Bahasa dan Pustaka in 1964 and after being selected as one of the school literature text books by the Ministry of Education of Malaysia, it was thereon printed almost every year. However, before Kassim Ahmad, W. G. Shellabear published it in Jawi and Latin script in 4 volumes in 1908 printed by Malaya Publishing House. Some parts of it was translated into Dutch by Niemann (1892) and Overbeek translated it into German and published it in Singapore in 1915 and in Australia in 1918. In Jakarta Balai Pustaka published it in 1939, 1948 and 1956, and Djambatan dan Gunung published it 1960. In 2010, Muhammad Haji Salleh did an English translation of the text based on the Kassim Ahmad's version, published by the Institut Terjemahan Negara Malaysia with the title The Epic of Hang Tuah. In 2012 Siti Hawa Salleh made a transliteration of the text Hikayat Hang Tuah based on the manuscript HHT MSS 1658 in the Perpustakaan Negara Malaysia.

\section{Secondary and Primary Sources Related to The Existence of Hang Tuah Malay Literary Secondary Sources}

As mentioned above, the original source that mentioned the name of Hang Tuah was the Hikayat Hang Tuah. Though many scholars such as Kassim (1966); Henk (2004), and others, regarded the Hikayat Hang Tuah more of a literary rather than historical work, there were indeed some elements of history mentioned in it, such as the description of the origin of the Malay kingdom at the Bukit Seguntang in Sumatera which could be associated with the Melayu kingdom in Palembang predating and followed by the Srivijaya kingdom, then the Bentan Kingdom, followed by the Singapura kingdom and finally the founding of the Malacca kingdom. However, no dates were mentioned for these events. There were also mentioned about the episodes of the parents of Hang Tuah moving to Bentan then to Malacca in search of greater fortune especially for their son Hang Tuah whom the father could see in him some sign of future greatness.

When the family was settled in Malacca residing within the vicinity of the settlement of the Bendahara or the Prime Minister of Malacca, Hang Tuah showed the first sign of his greatness, bravery and prowess when, still as a boy, he confronted and killed an agitated man who was wildly attacking and killing people on the street and was about to attack the Bendahara's party on their way to the king's palace. As a reward of his extraordinary courageous act, Hang Tuah was brought into the service of the state, and together with his four close friends they rose to become the warriors of Malacca, with Hang Tuah later to become the Laksamana or 
Admiral of Malacca, chosen based on his special qualities of leadership, valour, prowess and wisdom excelling above the others. It was as a Laksamana, Hang Tuah travelled to no less than 14 countries as the delegate of the Sultan of Malacca, for the purpose of forging diplomatic relation as well as for trades and commerce. In his travels to various countries, all sorts of exploits and acts of bravery were attributed to Hang Tuah and his party. Hang Tuah fought in many dwells and battles against various enemies on land and in sea, with vivid description of his bravery, courage and fighting prowess. On the flagship of the Sultan of Malacca the Mendham Berahi, Hang Tuah and his party travelled to Java, Pahang, Brunei, Palembang, Aceh, India, China, Ayuthia (Siam), Patani, Ryukyu, Jeddah, Mecca, Egypt and Istanbul. However, in one episode in the Hikayat Hang Tuah, the time when he was in Jeddah and was about to embark on a journey to Mecca to fulfil the Hajj rite, the date was 886 Hijrah (1481/1482 C.E.), being the only date mentioned in the text. (Kassim, 1966: 444).

Besides the Hikayat Hang Tuah, among other traditional Malay works that have mentioned the name Hang Tuah were the Sulalatus Salatin (Sejarah Melayu) compiled by Tun Sri Lanang in $1021 \mathrm{H}$ (1612 C.E.) and also the Tuhfat al-Nafis by Raja Ali Haji in 1870 C.E.

In the Sulalatu Salatin, Hang Tuah was mentioned in many places, the first instance was at the time of the preparation of Sultan of Malacca's marriage entourage to the kingdom of Majapahit in Java, where meticulous selection of suitable officials was made to accompany and guard the Sultan on the journey:

"The Sultan then selected young men of high breeding, 40 in numbers, and warriors of high standing also 40 in numbers...and amongst them nine are the most prominent; Hang Jebat, Hang Kesturi, Hang Lekir, Hang Lekiu, Hang Ali, Hang Iskandar, Hang Hussan, Hang Husin, Hang Tuah, indeed these nine are without peers. And Hang Tuah excelled above the others in term of cleverness, prowess, and bravery."

In the Tuhfat al-Nafis by Raja Ali Haji, he mentioned only once the name of Hang Tuah on page 9 as quoted below:

"The king of the kingdom Goa then presented a young prince, Dahing Mempawah, from a vassal state, to Sultan Mansur Shah of Malacca as a gift in return to the gift presented to him by the Malacca Sultan. It was this young prince who later became the famous warrior of Malacca, Hang Tuah, who killed Hang Jebat his close friend, in a dwell, after the later rebelled against the Sultan whom he thought had unjustly ordered the killing of Hang Tuah. In a show of defiant to the Sultan, Hang Jebat had occupied the Sultan's palaces and molested all the Sultan's maidens." (Tuhfat al-Nafis. Verginia Matheson Hooker (researcher), 1991: 134 \& 1998: 9).

The two local sources mentioned above, the Sulalatu Salatin and the Tuhfat al-Nafis, which described the existence of Hang Tuah, cannot be considered as primary sources, since they were written not during the time of Hang Tuah, but a few hundred years after him, the former about 102 years and the later about 369 years. However as secondary sources, they can be used to strengthen the argument in the primary sources, which will be described below. 


\section{Primary Sources as Proof of the Existence of Hang Tuah}

In order to prove the existence of persons in history or the occurrence of any events, there must be what is called the primary sources. Historical research encompasses two forms of sources, also known as "evidence": primary and secondary evidences. Historians describe the primary evidence as records of the actual words of someone who participated in or witnessed the events described, while secondary evidence records the findings of someone who did not observe the events but studied the primary evidence and reported them at a later date after the occurrence of the event. Primary evidence also may consist of artifacts belonging to, produced by or associated with the person being studied, for example weapons, apparels, ornaments, graphic, sculpture, food, body parts, dwellings, utensils, money, vehicles, etc. In order to prove the existence of Hang Tuah in history, the following primary sources are discussed.

\section{1) The Rekidai Hŏan: Ryukyu Kingdom Official Chronicle}

The original version of this writing known as the Rekidai Hŏan, an official chronicle of the Ryukyu kingdom, was written in Chinese between the year of 1431 to 1867 C. E. relating to Ryukyuan contacts with China, Korea, and eight Southeast Asian countries. It has nine sections and one annex. Section I describes the Ryukyuan-Korean relations, section II relation between Ryukyu and Siam, section III relation between Ryukyu and Malacca, section IV relation between Ryukyu and Palembang, Section $V$ relation between Ryukyu and Java, section VI relation between Ryukyu and Sumatra, section VII relation between Ryukyu and Sunda Kerapa (Kelapa), section VIII relation between Ryukyu and Patani, and section IX relation between Ryukyu and Annam (Atushu \& Mitsugu, 1969: v-vii).

Section III relation between Ryukyu and Malacca contains 16 documents or letters beginning from the year 1463 until the year 1511; ten letters were from the king of Ryukyu and six letters from Malacca. Three of the six Malaccan letters can be associated with Laksamana Hang Tuah. 


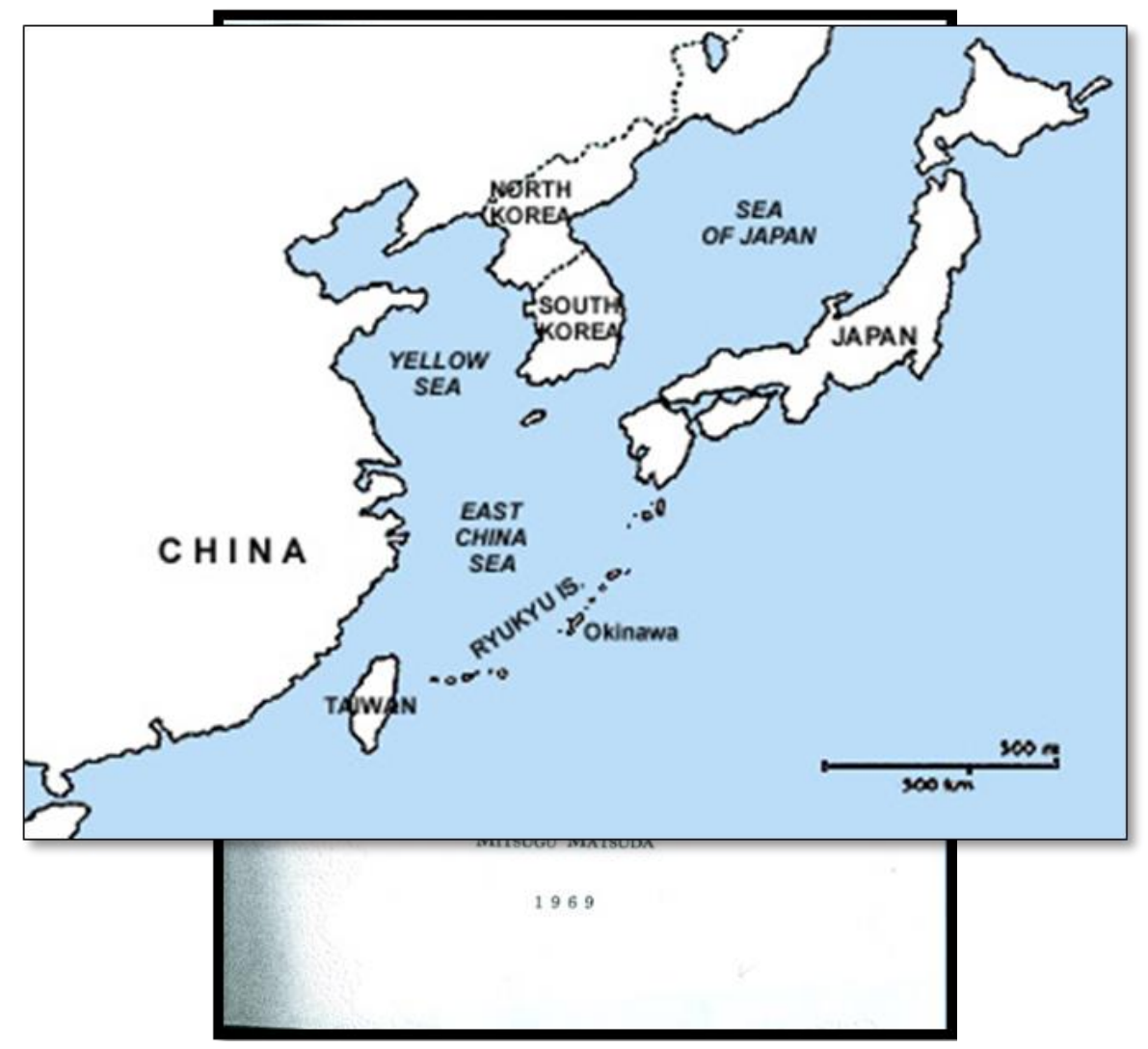

Figure 1: Ryukyuan Relations with Korea and the South Sea Countries: An Annotated Translation of Documents in the Rekidai Hŏan (Atushu \& Mitsugu, 1969).

Figure 2: Ryukyu Island Kingdom with its capital city Okinawa.

Below is the copy of the letter Document No. 9 from the Sultan of Malacca to the king of Ryukyu written in Chinese:

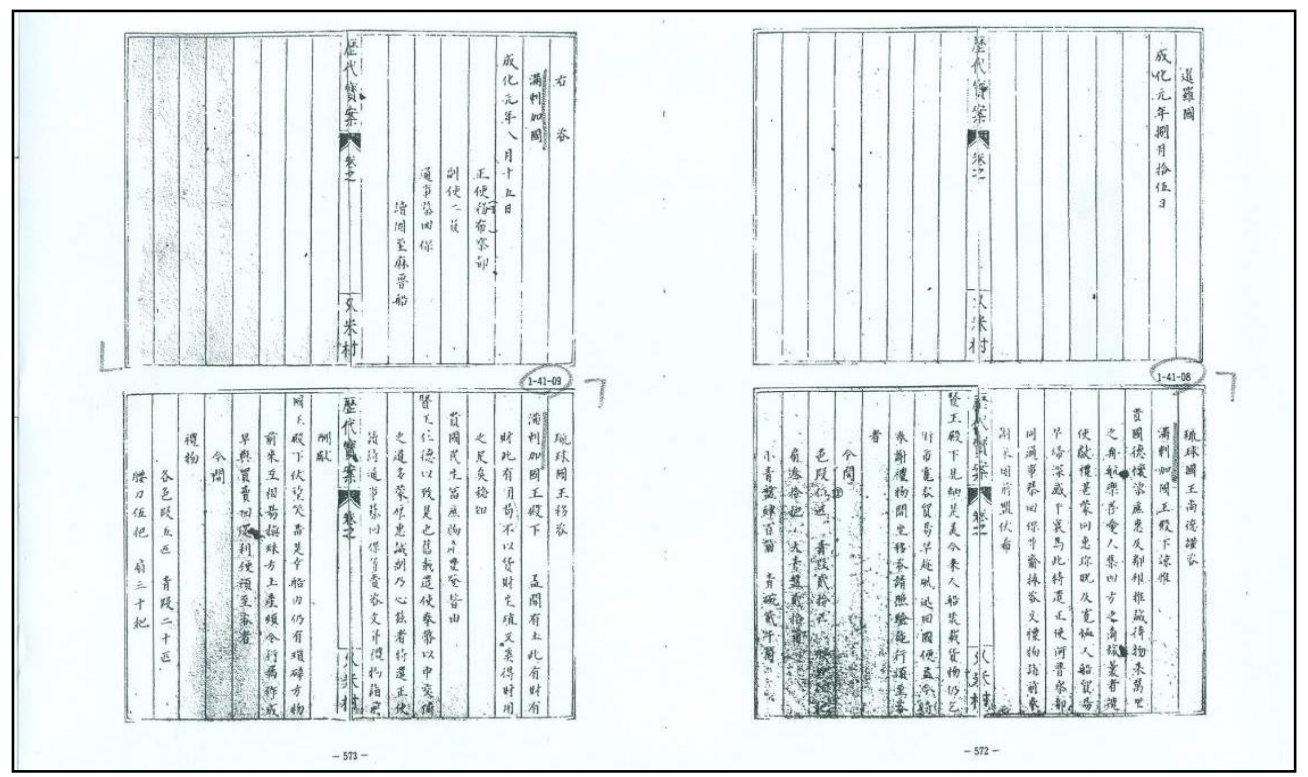

Figure 3: Document No. 9, a letter from the Sultan of Malacca to the King of Ryukyu (original Chinese version in the Rekidai Hŏan). 
Below is the translation of the letter into English by Atushu \& Mitsugu (1969: 116-118):

The King of the country of Malacca respectfully submits this dispatch to Your Majesty the King of the Country of Ryukyu.

We have learned with reverence that the Imperial bounty of the Middle Kingdom is farreaching. I am just six years of age, and I am grateful for the peace and welfare ensured for the little country by heavenly favors. It is hoped that Your Fatherly Majesty of Ryukyu will gratefully grant us many letters and presents.

You have dispatched your envoy, Interpreter Tei Raku, and others aboard your ship, with a cargo of local products, to proceed hither to present them. Merchant-travelers have come one after another. But alas! The distance over the sea is so great that we have not yet been able to return our thanks. It has been faithfully reported that more liberal treatment is accorded there [in Ryukyu], and much as we wish to make our way hence to pay tribute and express appreciation, we are generally in want of ship.

Mindful of the principle of neighborly relations, we are hereby expressing our feelings by means of sincere and humble presentation of gifts to return your kindness. We shall be most pleased if you will accept them with a smile.

Pray have pity on this destitute country of ours, Your Fatherly Majesty, and let us look forward with humility to your continued communication in succeeding generations and to our sympathy and grant of presents.

We have our respective territories, whose soils are rich and products abundant. For this reasons travelling merchants come swarming to us from far. [We request that] that you have your people engage in business [with our envoys] as soon as possible and send the envoys back to the country safely and speedily with the wind, accompanied by your envoys. This would be most beneficial to us. Let this dispatch be given to the addressee.

The presents are now listed:

Sha-nan-pu 10 boltSheng-che-ha 10 bolts

Na-mu-[na] 10 bolts Shan-nan-pu wen-ti-li 10 bolts

Huo-wai $\quad 10$ bolts

Ch'ng-hua 16/2/? [1480]

On behalf [of 'the king'] 
Below is another letter Document No. 10 written by the Laksamana to the King of Ryukyu (original version in Chinese in the Rekidai Hŏan)

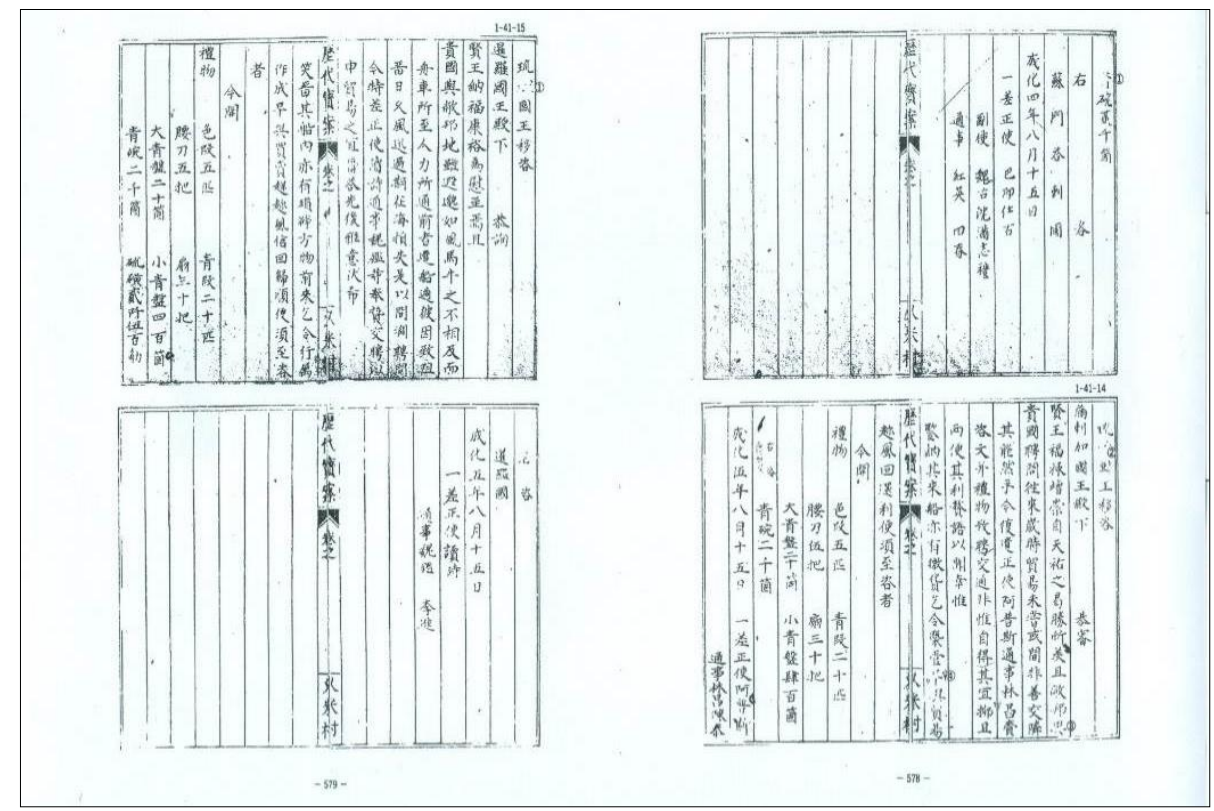

Figure 4: Document No. 10, a letter written by the Laksamana (original Chinese version in the Rekidai Hŏan).

Below is the translation of the letter into English by Atushu \& Mitsugu (1969: 119):

"Lo-shi-mana of Malacca respectfully submits this dispatch to Your Majesty the King of Rhukyu.

We have learned that one of your ships was cast ashore in Chiao-chih [northern Annan], and, wanting to obtain water, [the Rhukyuans] became engaged with bloody fight with people of Chiao-chih. Having learned of this, Lo-hsi-ma-na dispatched envoys aboard a small ship to the land of Chan-ch'en [Champa, Annam] and after a thorough investigation they found only two men, one of whom died of illness before long.

Now the envoys of the King of Rhukyu, including interpreter Tei Raku, having come to this country, and after they did their business peacefully, they returned to their country.

Lo-shi-ma-na is but a servant of Malacca, and thus a servant in the service of Your Majesty the King of the Country of Rhukyu [as well]. On behalf of the men remaining here [in Malacca i.e. the Rhukyu waif), I venture to submit this letter to Your Majesty and request a grant of one sword, one bow-adjusting tool, and a horse saddle. These are for use by this servant who comes begging, and I am your servant indeed.

The number of voyages of your ships in increasing each year, and we always receive presents. I hope you will give consideration to the unchanging feelings [faithfulness] of your servant. 
Long live the King!

Ch'eng-hua 16/3/2 [April 11, 1480]

Respectfully

Lo-hsi-.ma-na"

Another letter also written by the Laksamana on behalf of the Sultan of Malacca was the Document No. 15, rendered into English by Atushu \& Mitsugu (1969: 119) as below:

"[The King of] The Country of Malacca submits this reply to Your Majesty the King of The Country of Rhukyu.

Your percepts nourish and tend all people, and they look up to you as to the Great Mountain. Your wise rule permeates every corner and encourages the cultivation of honesty, talent and the sense of shame. In the seventh territories laws and regulations are enforced, and your prestige and authority are spread far and wide as are the rays of the sun and moon. You rule with the Mandate of Heaven and in accordance with the wishes of the people, and noble personages came from afar to enjoy your patronage. We are grateful for the favor of the Great Ming Empire.

Our brother king [referring to the King of Ryukyu] is always blessed with happiness and prosperity, and your glory last for thousands of years, the state of peace being ensured for your posterity forever.

Now your envoys and interpreters and others have come hither aboard a ship, bringing presents with them. Peacefully and without restriction we let them conduct their business. We ordered precious colored wine to be bestowed on them, we let your people set out on their homeward voyage.

We wish that your hills and rivers may last forever. Long live [the King!]

Lo-shi-ma-na in appreciation

Ma-an-shan to your Majesty the King of the Country of Rhukyu.

The present are listed below:

Chi-ti-pu20 boltsLin-wu-na12 bolts

Hsing-si-chih14 boltsShan-nan-pi4 bolts

Ch'eng-hua 17/3/? [1481]

On behalf of the King" 
Professor Atushu Kobata and Mitsugu Matsuda by basing on the dates of these letters i.e. 1480 and 1481, concluded that the Laksamana mentioned in these letters was none other than Hang Tuah, who was at that time in the service of Sultan Alaudin Ri'ayat Shah (14771488). Sultan Alauddin ascended the throne of Malacca while he was still a child, as mentioned in the above letter of 1480 , which concurred with the description in the Sulalatu Salatin that he ascended the throne while still a child after the death of his father Sultan Mansur Shah, who willed it on his deathbed:

“Pertaruhku anak kita Husin (nama asal Sultan Alauddin Ri'ayat Shah) ... Jikalau barang suatu salahnya, hendaklah dimaafkan oleh tuan-tuan kerana dia budak." (Husin is my choice (the real name of Sultan Alauddin Ri'ayat Shah before he was installed as the Sultan) ... If should he does any mistake you all must forgive him as he is still a child.") (Shellebear, 1967: 164).

The Sulalatu Salatin further confirmed that Hang Tuah was the Laksamana serving under Sultan Alauddin, who at one time was sent by the Sultan to Siak a vessel state of Malacca to punish the ruler for putting to death a person without the permission of the Malaccan Sultan. On his return the Sultan enquired:

"Maka Sultan Alauddin bertanya kepada Laksamana Hang Tuah perihalnya di Siak, semuanya dipersembahkan Ke bawah Duli Sultan Alauddin." ("Sultan Alauddin enquired the Laksamana Hang Tuah about the affair in Siak, and thus every detail was described by him to his majesty Sultan Alauddin.") (Shellebear, 1967: 178).

Another primary source of evidence is an old dagger or keris found in Okinawa in the vicinity of the ruin of the royal Enkakuji Temple grounds near the 15th century Shurijo Castle. According to the Okinawa Prefecture Archaeological Centre officials "the blade was found buried along with other items, including a clay plate with carvings of a dragon shaped boat, a glazed pot, a gold-plated door hinge and a metal door skirting." The blade measuring $22.1 \mathrm{~cm}$ from the tip to hilt with nine curves or "lok", was found without the handle and sheath, as the wooden parts had been destroyed. According to Kurayoshi Takara a historian from the University of The Ryukyu, who has been to Malaysia and Malacca to carry out research on the ancient ties the Kingdom of Ryukyus had with Southeast Asian kingdoms, who also made the study on the keris and compared it with those found in Malacca, concluded that "I personally believe it could have been from Malacca because the Ryukyu Kingdom had started trading with Malacca in the 15th century."

Below is the photographs of the keris, being handled by an Okinawa museum official: 

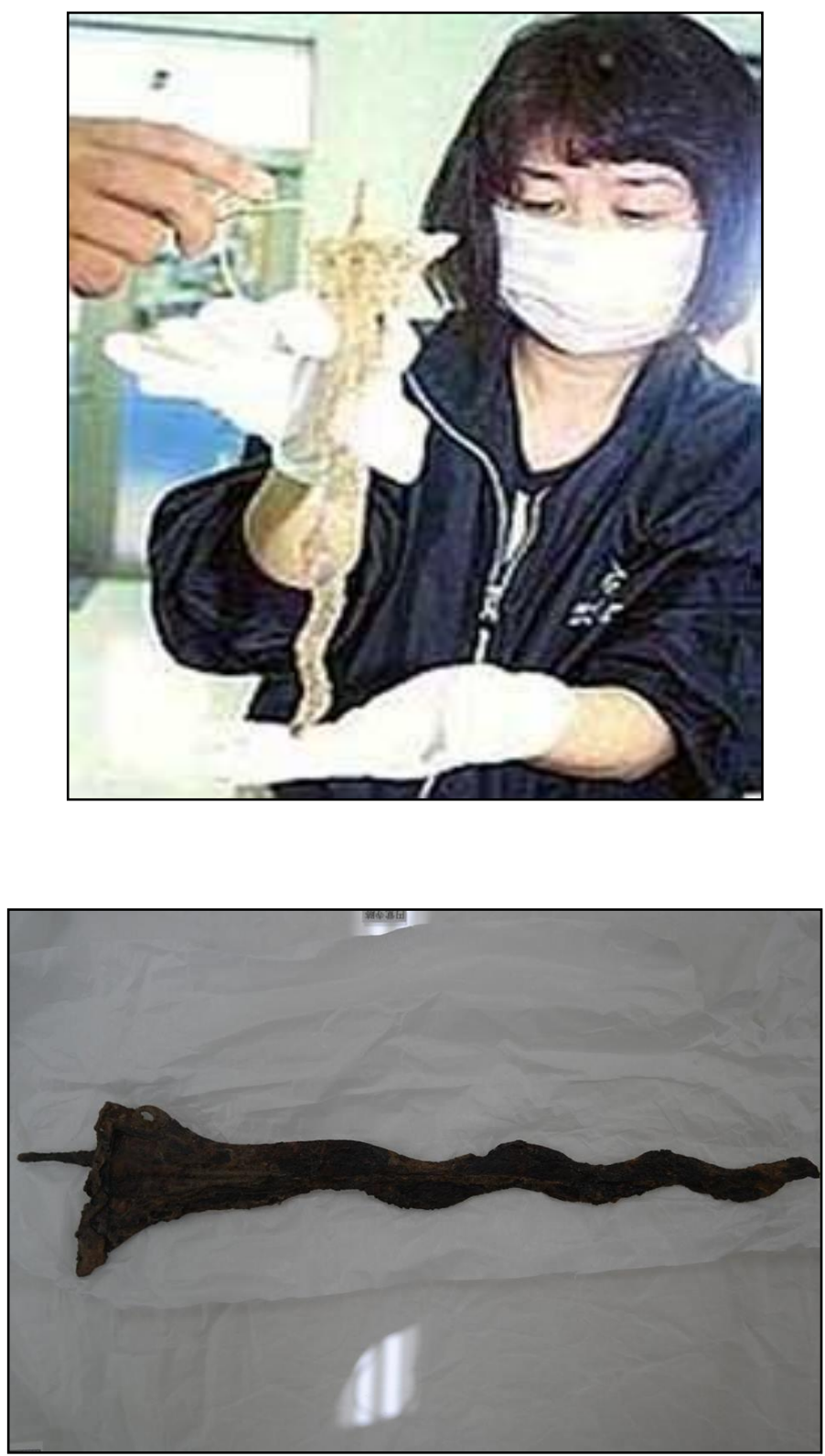

Figure 5: The ancient keris with nine curves or "lok" without the handle and sheath found in in the vicinity of the ruin of the royal Enkakuji Temple grounds near the 15th century Shurijo Castle Okinawa, believed to be from Malacca.

Two other primary Chinese documents connected to Malaccan history are the Ming Shi (History of the Ming Dynasty), and the Hsing-Ch'a-Sheng-lan (The Overall Survey of the Star Raft) by Xin Fei the official chronicler of Admiral Zeng He.

\section{2) The Ming Shi document}

The Ming Shi document mentioned that the Chinese relationship with Malacca was started in the year 1403 C.E. by the Ming Emperor Cheng Zhu who sent a delegation headed by the Interior Minister Yin Qing to deliver presents in the forms of silk robe, golden keys, various types of curtains, etc. The head of Malacca Parameswara was very happy to receive them, and in return sent a representative together with the returning Chinese delegation in 1405. These delegations were followed by several more, both from the Ming Emperor and 
the king of Malacca. In 1408 The Ming Emperor sent Admiral Cheng Ho (Zheng He) to Malacca, and followed by his second visit in 1412, and third and final visit in 1430 bringing various presents with every visit. In return the Malacca kings also sent delegations to China as well personal visits done in 1411 by Parameswara and in 1433 by Seri Maharaja (Liang, 1996: 64). However, in the Ming Shi document there was no mentioned of Laksamana Hang Tuah, as he was just born in 1431.

\section{3) The Hsing-ch'a-sheng-lan (The Overall Survey of the Star Raft) Document by Xin Fei.}

This document was written by Xin Fei or Hsin Fei the official chronicler of Admiral Zheng He, who accompanied the Admiral in his voyages from 1385 to 1436. The document was translated into English by Mills (1996) and published as a book: Hsing-ch'a-sheng-lan: The Overall Survey of the Star Raft. Wiesbaden: Otto Harriassaowittz. An example of the description of Malacca in 1405 by Xin Fei in the document, is as follows:

"The country of Man-la-chia- kuo (the country of Malacca), formerly this place was not called a "country" (kuo). Starting one's journey from Palembang, with fair wind, one arrives here after eight days and nights. The people live beside the sea. There is a single hill [Bukit China] with few people on it. They are in a state of subjection to Siam, each year they remit forty liang of gold in payment of their tax... The climate is hot and cool at night. Men and women do up their hair in a chignon [sanggul]. The skin of their bodies is black lacquer [but] among them are some fairer ones who are of Chinese origin. The customs are honest and generous. [In seeking livelihood] they sift [tin] in the streams and net fish in the sea... Their houses are like storied pavilions, that is, they are not set up in an orderly way....

The commodities used [in trade with them] are such things as blue and white porcelain articles, melted beads of colours, coloured thin silk and gold and silver.

In the seventh year of Yung-lo (1409), the emperor ordered the principal envoy, the Grand Eunuch Zheng $\mathrm{He}$, and others to forward instructions and to bestow [upon the ruler] a pair of silver seals, a cap, girdle, and a robe. [Zheng He also] set up a stone tablet [stating that this] territory had been raised to [the rank of] the Country of Malacca. From then on Siam did not dare to disturb [Malacca].

In the thirteenth year of Yung-lo (1425), the principal chief [of Malacca, desirous of] showing gratitude for the imperial favours, took his wife and son and crossing the seas, came to Court [of emperor Ming] to offer thanks and submit innumerable articles as tribute." (Xin (Mills, Trans.), 1996: 54-55).

The Chinese documents are very valuable primary sources that confirmed the existence of the Malacca kingdom under various kings and Sultans, and the establishment of cordial relationship between the two kingdoms in the $15^{\text {th }}$ Century. The Ryukyu official document, the Rekidai Hŏan in particular, affirmed with definite certainty the existence of Laksamana Hang Tuah, who had personally travelled to the Ryukyu Kingdom in 1480 and 1481, representing the Sultan of Malacca in strengthening diplomatic relation and establishing commercial activities. 


\section{4) The Portuguese Source}

The Portuguese source is a document The Commentaries of the Great Afonso Dalboquerque: Second Viceroy of India, original version in Portuguese by Braz Dalboquerque published in 1557, the English translation with the above title was by Walter de Gray Birch published in 1884 by Haklyut Society of London. The original version in Portuguese by Braz Dalboquerque was based on the dispatches by his father Afonso Dalboquerque to King Don Emmanuel of Portugal (1495-1521) $)^{3}$.

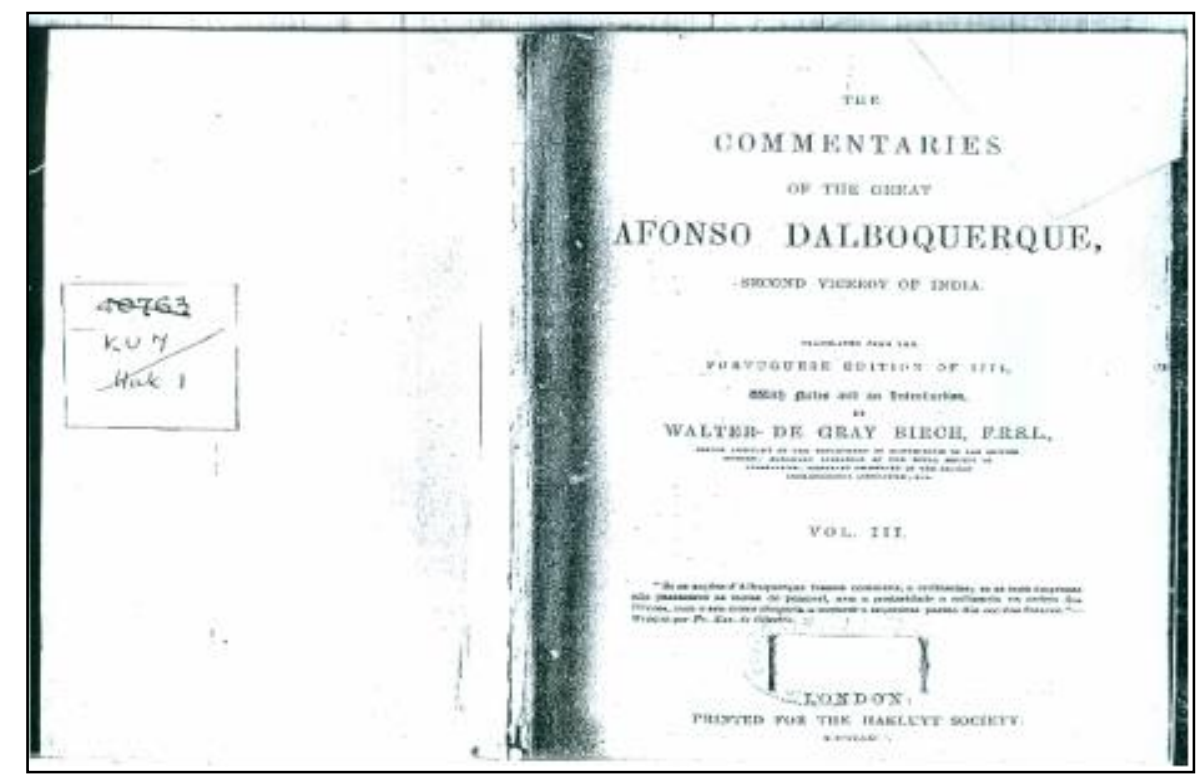

Figure 6: The Commentaries of the Great Afonso Dalboquerque: Second Viceroy of India, English translation by Walter de Gray Birch published in 1884 by Hakluyt Society London.

On page 90 of the above document, it is mentioned that the Laksamana was 80 years old at the time of the conquest of Malacca by the Portuguese in 1511:

"This Lassamane was a man of eighty years of age, a good soldier, of good repute and great knowledge: when he perceived that the king of Malacca was lost, he went and settled in Singapura, and after Afonso Dalboquerque was in possession of Malacca, he came down to the river of Muar declaring he was desirous of returning to live in Malacca... Nevertheless, he would not come, and it was thought that some Moors in Malacca... had written something to this Lassamane, whereby they have prevented his coming, for they feared that as he was a man of uncommon capabilities, Afonso Dalboquerque would seize the opportunity to make use of him for the governing of Malacca." (The Commentaries, p. 90) 


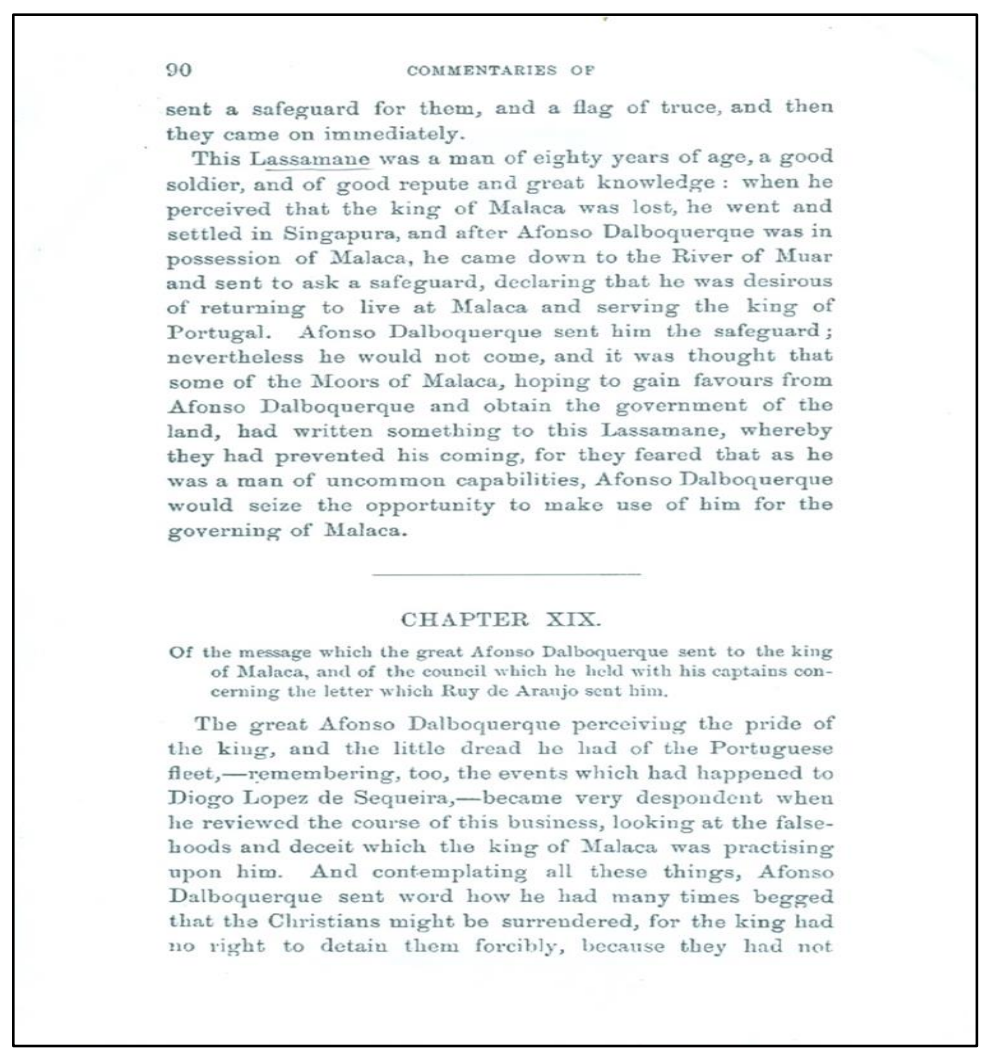

Figure 7: The Commentaries of the Great Afonso Dalboquerque: Second Viceroy of India, p.

90.

Based on the statement in the The Commentaries of the Great Afonso Dalboquerque: Second Viceroy of India, on page 90 above, that Laksamana Hang Tuah was 80 years old at the time when Malacca fell to the Portuguese in 1511, then it can be deduced that he was born in 1431. Based on the description in the Sulalatu Salatin, he had served under four Malacca Sultans; Sultan Muzaffar Shah (1446-1459), Sultan Mansur Shah (1459-1477), Sultan Alauddin Ri'ayat Shah (1477-1488) and the earlier phase of the reign of Sultan Mahmud Shah (14881511).

\section{5) The Vijayanagara of India Source}

Vijayanagara also known as Kernataka Empire, located in the Deccan Plateau South India, was established in 1336 by Harihara I and his brother Bukka Raya I from the Sangama Dynasty, and reached its peak of glory under Deva Raya II's rule (1424-1446) where it succeeded in completely conquering southern India such as Kondavidu, defeating the ruler of Quilon as well as other chieftains, extending the empire from Odisha to Malabar and from Ceylon to Gulbarga, and also taking over a lot of the major Indian ports. However, the empire collapsed in the year 1646 due the incursion and conquest by the Bahamani Muslim kingdom. The centre of the empire was in Vijayanagara and its main port was Nagapattinam on the east or Coramandle coast of India. The ruins of the empire is located in current day Hampi district South India and was named as a UNESCO World Heritage Site, with the remain of beautiful stone buildings, temples, fine carvings and sculptures located on walls and chambers of the buildings. 

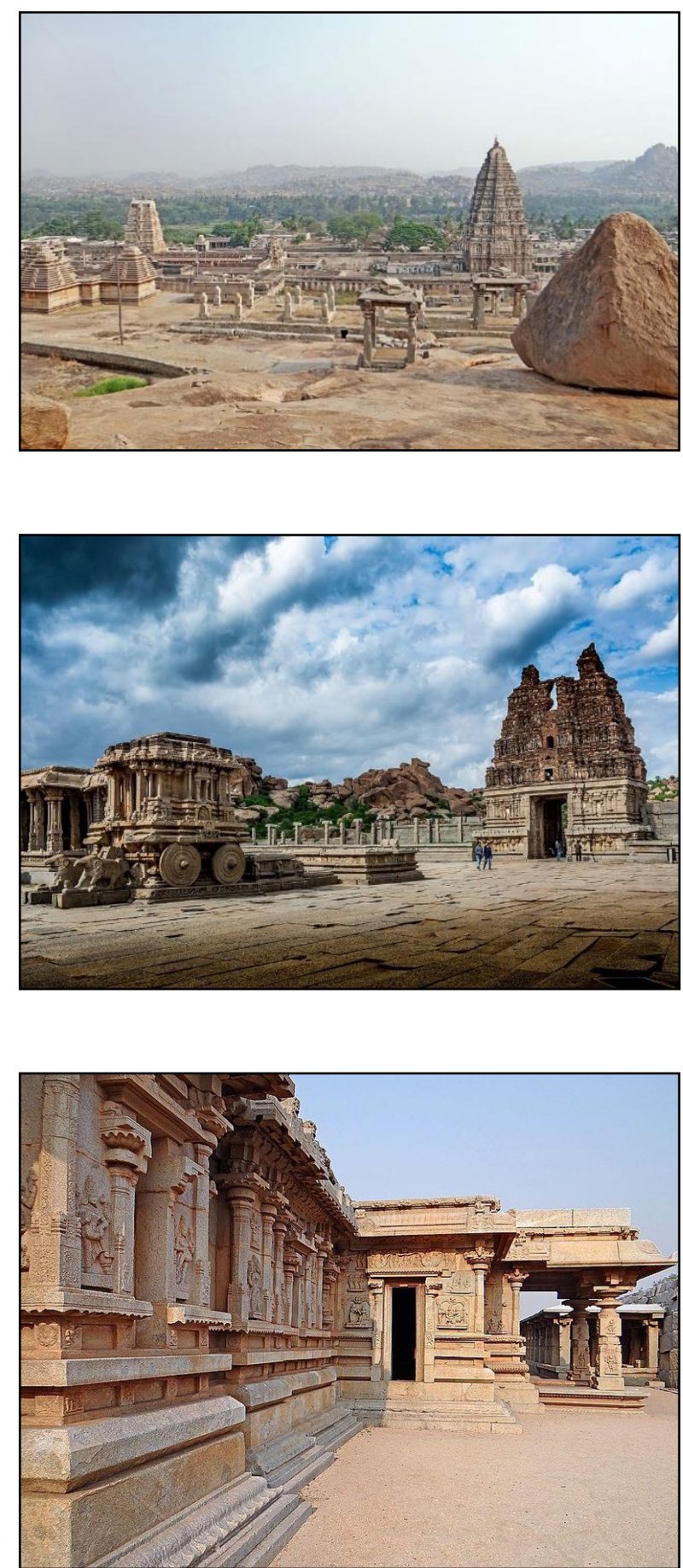

Figures 8: Ruin of buildings of the Vijayanagara Empire located at the present day Hampi District in South India.

Jawaharla Nehru in his book The Discovery of India (1945/196 9: 205) mentioned that trading relationship between South India and the Malay Archipelago started in the beginning of the first century C.E. and flourished during the time of Srivijaya kingdom from $7^{\text {th }}$ Century to $14^{\text {th }}$ Century, with its peak during the $8^{\text {th }}$ Century. During the ascendency of the Malacca Sultanate in the $15^{\text {th }}$ Century, there were direct shipping connections between Malacca and ports in the Coromandel coast of India, the main one being Nagapattinam the chief port of Vijayanagara. 


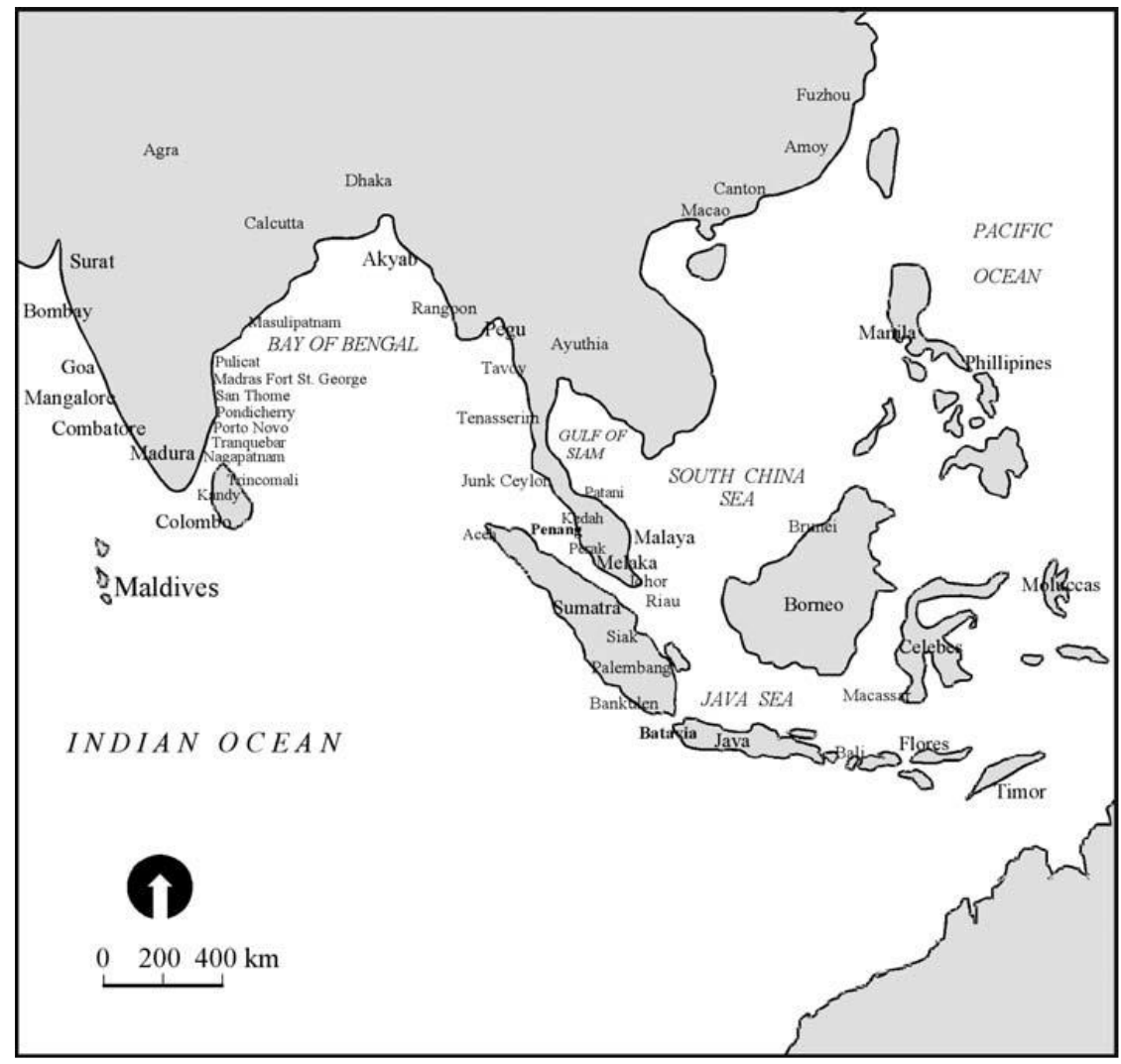

Figure 9: Trading ports in the Coromandel Coast of India and ports in the Malay Archipelago, having close trading connection especially between the port of Malacca with Pulicat, Pondicherry, Karaikal and Nagapattinam.

In the Hikayat Hang Tuah, the suggestion to send a delegation from Malacca to Vijayanagara was initially mooted by the Sultan of Malacca:

Maka titah Baginda, "Hai mamak Bendahara, adapun pada bicara kita, kita hendak mengutus ke Benua Keling kepada saudara kita. Apa bicara Bendahara dan Temenggung dan Laksamana...? Hai mamak Bendahara, siapa baik disuruhkan ke benua Keling itu?" Maka sembah Bendahara, "Ya Tuanku Shah Alam, pada bicara patik baik juga tuanku mengutus ke benua Keling... kerana baginda itu raja besar... Pada bicara patik, siapatah selain daripada Laksamana, kerana Laksamana tahu akan bahasa Keling, tambahan pula tahu perintah segala raja?" (The Monarch said, "My dear Prime Minister (Bendahara), my opinion is that we should send a delegation to the Kalinga Empire to our brother king there, what do you say Prime Minister, Temenggung and Laksamana...? and whom should we send?" The Bendahara replied, "Verily Your Majesty, my humble opinion is in full agreement with Your Majesty's suggestion to send such a delegation, as the king of the Kalinga Empire is also a great king... And in my opinion the most suitable person to be send (as head the delegation) is none other than the Laksamana, as he is conversant in the Keling language and moreover familiar with royal protocols of the palace.") (Kassim, 1966: 339).

After meticulous travel preparations and purchasing of trading goods, the delegation proceeded to Vijayanagara, with an armada of 13 ships headed by Hang Tuah on the Mendam 
Berahi. The sea voyage took 18 days; 8 days from Malacca to Birma Dewa Islands (probably old name of Andaman Islands), 3 days to the Coromandel Coast and 7 more days to the port of Nagapattanam in Vijayanagara Empire. (Kassim, 1966: 340).

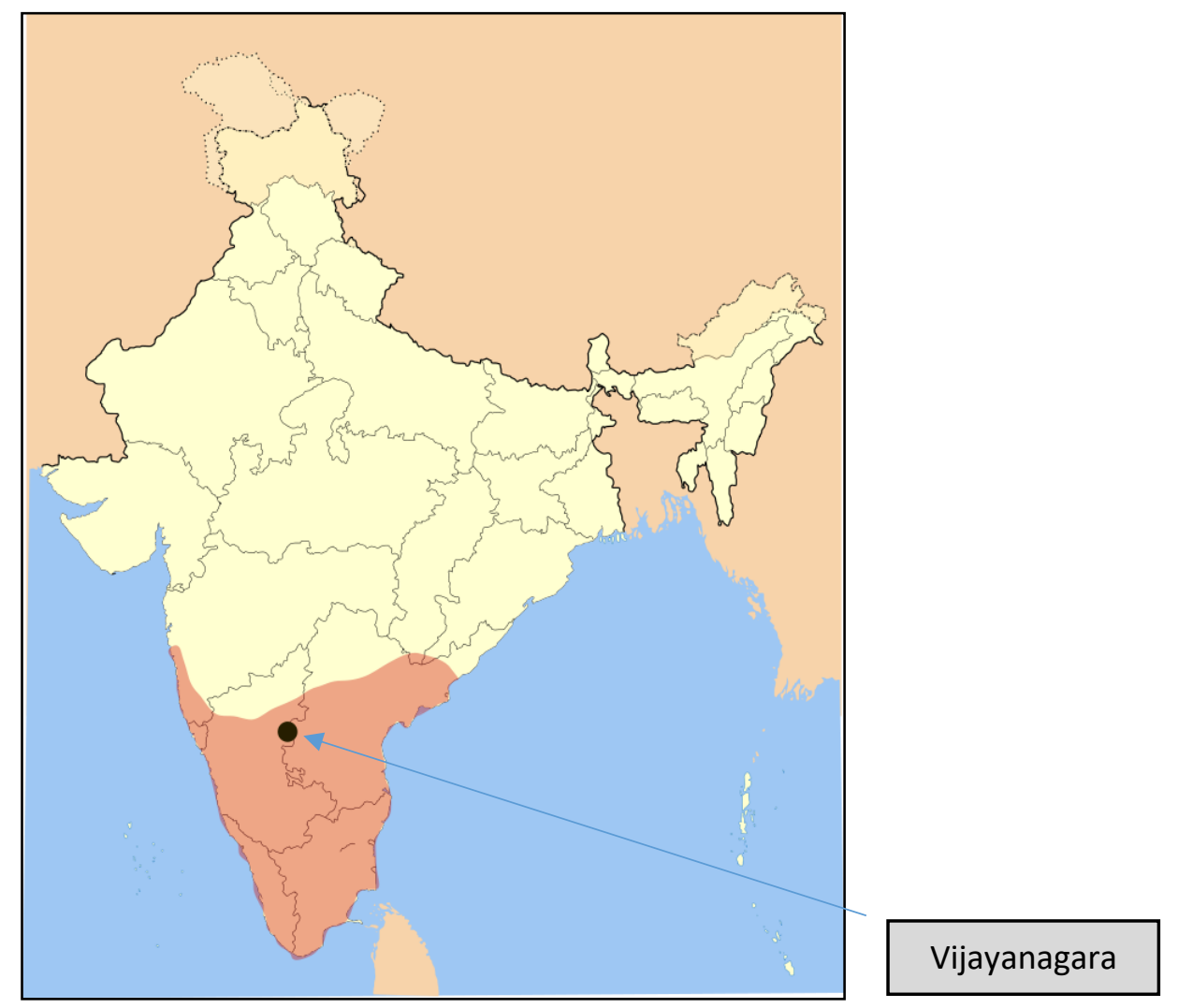

Figure 10: Vijayanagara Empire at its height extended throughout south India including Ceylon, with its centre at Vijayanagara.

In the Hikayat Hang Tuah, when Hang Tuah was having an audience with the king of Vijayanagara Kisna Rayam (corresponding to his real name Krishna Dewa Raya in the Vijayanagara history), the king requested Hang Tuah to tame and ride a big Persian horse, Tezi, about six feet tall and wild as a lion and none dare to ride it. Hang Tuah with his exceptional skill managed to ride it and tame it, which gave rise to great admiration from the king and all those who were present (Kassim, 1966: 352-353). This episode was immortalized in the form of a carving on a wall of a building in the ruin at Hampi, which is still standing. This fact was confirmed by the Indian curator on duty at the site, when we visited the site in 2017. 


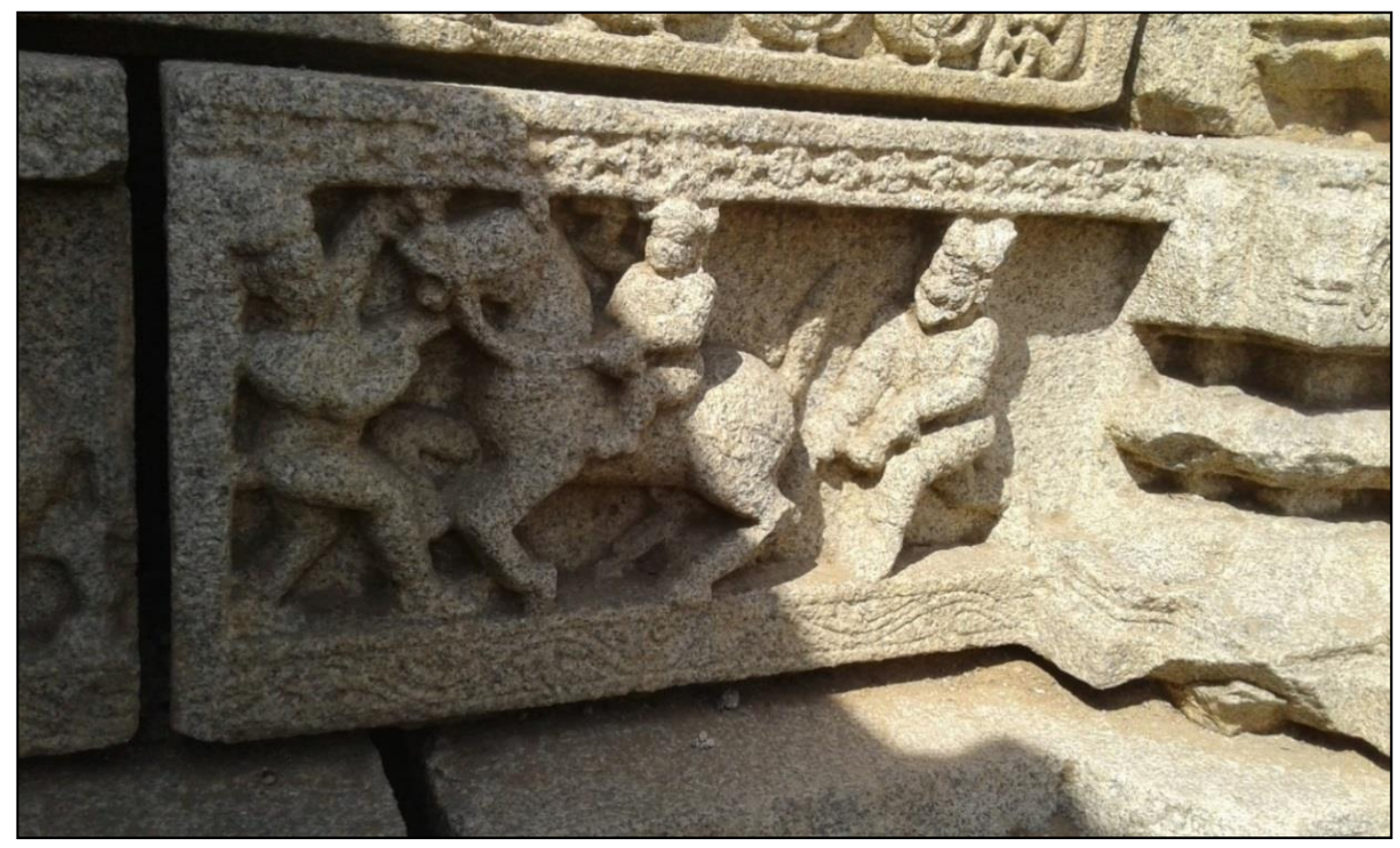

Figure 11: A carving on a wall of a building in Hampi the site of the Vijayanagara ruins, showing Hang Tuah riding the Tezi horse, identified by the shape of his face and head gear or "tongkolok" which differed from those of the Indian men, and confirmed by the Indian curator on duty at the site.

Based on the four primary evidences, and complemented by at least one secondary evidence the Malay literary work Sulalatu Salatin discussed above, we can conclude with quite strong certainty of the existence of Laksamana Hang Tuah in history. He served under four Sultans of Malacca as a warrior, diplomat, admiral as well as international trader, traversing the seas to the east as far as China and to the west as far as Istanbul the capital city of the Ottoman Turkish Empire. He was born in 1431 C.E. and was still alive in 1511 age 80 years old when Malacca fell to the Portuguese, and he went to settle in Singapore.

\section{Hang Tuah: A Malay Icon Transcending Time}

The roles of Hang Tuah as a warrior, admiral with a noble moral and ethical personality; his bravery, courage, prowess and loyalty, his knowledge as a wise diplomat and a polyglot international trader and traveler, made him nothing less than an icon to be modeled upon by his later generations transcending time. There were seven excellent elements of his character that made him a Malay icon or a model and a gentleman par excellence. These excellent elements can be nurtured and instilled into the personality of the Malays at anytime and anywhere, so as to ennoble their characters as well. These elements are:

1) Undivided loyalty to the leaders and kings:

Sembah Hang Tuah kepada Raja Siam, "Daulat tuanku, patik hamba Ke bawah Duli Phra Chau, mana titah patik junjung. Tetapi si-Tuah tiada menghilangkan nama tuannya." (Hang Tuah said to the Siamese King, "Your Majesty, I am but a servant of Your Majesty Phra Chau, whatever your order I will obey. However, as a servant to my own king I will never dishonour his name.") (Kassim, 1966: 391). 
2) Arduously defending his own honour and self-respect:

"Maka titah Chau Phrau, "Laksamana jangan amarah." Maka Laksamana pun menyembah, "Daulat tuanku patik mohonkan ampun. Ada pun hulubalang Melayu itu tiada dapat mendengar kata yang keji di tengah majlis." (Phra Chau said, "Laksamana, do not be angry." Hang Tuah replied, "Your Majesty, please pardon me. Verily a Malay warrior cannot accept humilation in public.") (Kassim, 1966: 391).

3) Wise, smart, and quick thinking with wide knowledge and high communicative skill:

The protocol to have an audience with the Siamese king at his court was to shuffle on one's hands and buttock in obeisance, which was against the Malay's custom. Hang Tuah is his wisdom did not protest and refute outright but by giving an excuse that he suffered an itchiness on his body, therefor unable to shuffle on his buttock in obeisance, as such he was excused from the Siamese protocol and instead did obeisance according to the Malay custom by slight bowing of the head with hands clasp together infront of him. (Kassim, 1966: 389).

4) Deep Islamic religious knowledge, highly cultured with noble moral and ethical values, and proficient in many languages:

He studied the whole Qur'an as a child and then went on to study the Islamic knowledge and Arabic language, and he mastered 12 languages by learning them from various teachers of the languages, such as Javanese, Indian, Siamese, Arabic, Persian, Chinese, etc.

5) Studied and mastered the arts of fighting and the way of the warrior:

He was trained in the arts fighting and dwelling with weapons by the most venerable masters in the Malay Archipelago, namely Aria Putera in Bentan and Sang Persata Nala in Java, and thus acquired the highest fighting skill and prowess.

6) Unparalleled courage and valour, against any enemy never back down till the end:

When confronted by 40 hired killers to kill him while in Majapahit, he single handedly faced them and fought them gallantly killing most of them, while the remainder ran away. (Kassim, 1966: 270).

7) An imposing and noble countenance with a very attractive appearance and dignified personality:

The description of Hang Tuah's imposing personality was vividly described in both in the Hikayat Hang Tuah and the Sulalatu Salatin:

"Adapun akan Laksamana Hang Tuah, barang tempat ia pergi, gegak gempita bunyi orang daripada hebat melihat sikap lakunya. Jika ia di pasiban, pasiban gempar, jika di panggungan, panggungan gaduh. Dan segala perempuan Jawa anak dara-dara, jikalau ia berjalan di pasar atau barang ke mana, banyaklah yang gila akan Hang Tuah." 
("Indeed, Laksamana Hang Tuah, wherever he went, he invoked great excitement among the onlookers, impressed by his imposing countenance, attractive appearance and dignified mannerism. If he went to the market place, the market was in uproar with excitement, if he went to the theatre, the theater became wild with excitement. And all the Javanese young virgins wherever he went to the bazaar or anywhere else, many became madly enamored towards Hang Tuah.") (Samad, 1979: 115).

\section{Conclusion and Implication}

This article has successfully proved the existence of Laksamana Hang Tuah in history, by basing the arguments on three primary evidences and one secondary source. The primary evidences are the kingdom of Ryukyu's official chronicle the Rekidai Hŏan, the Portuguese' text of The Commentaries of the Great Afonso Dalboquerque: Second Viceroy of India, and the South Indian Vijayanagara's sculpture of Hang Tuah riding on the Tezi horse found on the wall of one of the buildings among the ruins in Hampi, South India. The secondary evidence as found in the Sulalatu Salatin the Malay chronicle of the Malacca Sultanate, compiled in 1612 by Tun Seri Lanang, confirmed the fact that when Hang Tuah visited Ryukyu Kingdom in 14801481, the Sultan of Malacca then was Alauddin Ri'ayat Shah. The Rekidai Hŏan of Ryukyu and the Sulalatu Salatin concurred in mentioning the fact that when Sultan Alauddin ascended the Malacca throne, he was still a child.

The second findings is regarding the seven elements of the noble character and personality of Hang Tuah that made him a Malay a gentleman par excellence and an icon to be the model for the Malay community. These excellent elements of his noble character can be nurtured and instilled into the personality of the Malays at anytime and anywhere, so as to strengthen and ennoble their characters as well. On that score the character of Hang Tuah could and should be elevated to be the cultural hero of the Malays, as has been suggested by one of the Malaysian Literary Laureates Emeritus Professor Muhammad Haji Salleh that "Hang Tuah is the nonpareil of culture heroes".

\section{Corresponding Author}

ROZITA CHE RODI (PhD) ita_cherodi@upm.edu.my is a Senior Lecturer at the Department of Malay Language, Faculty of Modern Languages and Communication, Universiti Putra Malaysia, 43400 UPM Serdang Selangor, Malaysia, specializing in Semantics: Cultural Semantics, Lexical Semantics, Semantic Field and Malay Thought and Civilization.

\section{References}

Atushu, K., \& Mitsugu, M. (1969). Ryukyuan Relations with Korea and the South Sea Countries: An Annotated Translation of Documents in the Rekidai Hŏan. Kyoto: Kawakita Printing.

Braginsky, V. I. (1990). Hikayat Hang Tuah: Malay Epic and Muslim Mirror. KITLV, Vol, 146. 4e afl.

Cortesao, A. (ed.). (1944). The Suma Oriental of Tom Pires and the Book of Francisco Rodrigues, London: Hakluyt Society.

Dalboquerque, A. (Trans.) Walter de Gray Birch. (1880). The Commentaries of the Great Alfonso Dalboquerque: Second Viceroy of India. London: The Hakluyt Society.

Dames, M. L. (ed.). (1918-21). The Book of Durante Barbossa. London: Hakluyt Society.

Hashim, M. (2013). Navigating the Odyssey of "Mendam Berahi" (the Suppressed Passion), the $15^{\text {th }}$ century Malacca Sultanate ship: lessons for the future Malay civilization. 
Proceeding in the International Conference on Malay Excellence (II) "Nusantara Maritime Culture and Heritage: Their Relevance to Current Economic and Social Development of the Malays". 11-12 September, 2013. Organized by the Research Centre for Malay Excellence University of Malaya.

Hashim, M., \& Rohaidah, K. (2015). Hang Tuah: Catatan Okinawa. Serdang: Penerbit UPM.

Henk, M. J. M. (2004). "An epic that never was an epic: The Malay Hikayat Hang Tuah". In Jansen, J., \& Henk, M. J. M. (eds.) 2004. Epic Adventures: Heroic Narratives in the Oral Performance Traditions of Four Continents. New Brunswick/London: Transaction Publishers (pp. 128-139).

Hooker, V. M. (Researcher). (1998). Tuhfat al-Nafis. Karya Agung Melayu. Kuala Lumpur: Yayasan Karyawan.

Kassim, A. (Researcher). (1966). Hikayat Hang Tuah. Kuala Lumpur: Dewan Bahasa dan Pustaka.

Liang, L. (1996). Hubungan Empayar Melaka-Dinasti Ming Abad ke-15. Bangi: Penerbit Universiti Kebangsaan Malaysia.

Mills, J. V. (1930). Eredia's Description of Malacca, Meridional India and Cathay. JMBRAS, Vol. $8, \mathrm{pt} 1$.

Muhammad, S. (2003). Hang Tuah Bercakap Oghang Puteh: Terjemahan dan Penjelmaan Hang Tuah dalam Bahasa Eropah". Prosiding Seminar Kebangsaan Hikayat Hang Tuah: Takkan Melayu Hilang Di Dunia, pada 26-27 September, 2003, di Universaiti Sains Malaysia, Pulau Pinang.

Muhammad, S. (Trans.) (2011). The Epic of Hang Tuah. Kuala Lumpur: Institut Terjemahan Negara Malaysia.

Muhammad, Y. H. (1989). Kesultanan Melayu Melaka. Kuala Lumpur: Dewan Bahasa dan Pustaka.

Rohaidah, K., Hashim, M., \& Shamshul, K. A. (2017). Hang Tuah: Catatan Vijayanagara. Serdang: Penerbit UPM.

Samad, A. A. (2013). Sulalatus Salatin Sejarah Melayu. Edisi Pelajar. Kuala Lumpur: Dewan Bahasa dan Pustaka \& Kementerian Pendidikan Malaysia.

Samad, A. A. (1979). Sulalatus Salatin Sejarah Melayu. Kuala Lumpur: Dewan Bahasa dan Pustaka \& Kementerian Pelajaran Malaysia.

Shellabear (ed.). (1967). Sejarah Melayu. Kuala Lumpur: Oxford University Press.

Shunzo, S. (1963). The Rekidai Hŏan. Journal of the American Oriental Society. LXXXIII (January-March, 1963). Pp. 107-113.

Shunzo, S. (1963). Ryukyu and Southeast Asia. Proceeding in the $15^{\text {th }}$ Annual Meeting of the Association for Asian Studies, at Philadelphia, March 25-27, 1963. Pp. 387.

Sulastin, S. (1983). Hikayat Hang Tuah: Analisis Struktur dan Fungsi. Yogyakarta: Gajah Mada University Press.

Geoff, W. (Trans.) (2005). Southeast Asia in the Ming Shi-lu: an open access resource. Singapore: Asia Research Institute and the Singapore E-Press, National University of Singapore, (http://epress.nus.edu.sg/msl). Accessed April 2021.

Wake, C. H. (1983). Melaka in the fifteenth Century: Malay Historical Traditions and the Politics of Islamization. In Sandhu, K. S., \& Paul W. (Eds.). (1983). Melaka: The Transformation of Malay Capital c. 1400-1980. Kuala Lumpur: Oxford University Press.

Winstedt, R. O. (1958). A History of Classical Malay Literature. In JMBRAS XXXI, iii. 1958.

Xin, F. (1996). (Trans.) Mills, J. V. G. Hsing-ch'a-sheng-lan: The Overall Survey of the Star Raft. Wiesbaden: Otto Harriassaowittz. 